\title{
A Mini-Review of Human Studies on Cholesterol-Lowering Properties of Probiotics
}

\author{
Bhagavathi Sundaram Sivamaruthi * $\mathbb{C}$, Periyanaina Kesika $₫$ and Chaiyavat Chaiyasut * \\ Innovation Center for Holistic Health, Nutraceuticals, and Cosmeceuticals, Chiang Mai University, Chiang \\ Mai-50200, Thailand; p.kesika@gmail.com \\ * Correspondence: sivasgene@gmail.com (B.S.S.); chaiyavat@gmail.com (C.C.); \\ Tel.: +66-5394-4340 (B.S.S. \& C.C.); Fax: +66-5389-4163 (B.S.S. \& C.C.)
}

Received: 27 August 2019; Accepted: 25 September 2019; Published: 14 October 2019

\begin{abstract}
Cardiovascular diseases (CVD) are the major health issue of modernized society with a high mortality rate. Lifestyle, genetic makeup, and diet are some of the major influencing factors associated with CVD. The dyslipidemia is one such factor related to the development of several CVD. Many studies proved that the consumption of probiotics confers several health benefits. Several studies reported the evaluation of the cholesterol-lowering ability of probiotics (probiotics that showed positive effect in vitro and in vivo studies) in human volunteers. The current review summarizes the outcomes of human studies on the cholesterol-lowering property of probiotics. Probiotic consumption significantly improved the health status of hypercholesteremic patients by reducing the low-density lipoprotein cholesterol, total cholesterol, triglyceride levels, and increased the high-density lipoprotein cholesterol. The probiotic supplementation improved the lipid profile of diabetic patients, and obese people as well. However, not all probiotic interventions are effective against dyslipidemia. The results are controversial and depend on several factors such as probiotic strain, dose, duration of the treatment, lifestyle changes, etc. This literature survey indorses additional studies on the cholesterol-lowering property of probiotics, which could help to reduce the risk of CVD and other dyslipidemia associated health issues.
\end{abstract}

Keywords: probiotics; hypocholesteremia; cardiovascular diseases; cholesterol-lowering lipids; microbiota

\section{Introduction}

Cardiovascular disease (CVD) is one of the major health issues with a high mortality rate ( 17.7 million deaths/year) [1]. The medical expenses to manage the CVDs are predicted to be tripled by 2030 [2]. Though genetics, microbiome, diet, lifestyle, and metabolic syndrome are the factors associated with the development of CVD, dyslipidemic condition (characterized by the elevated level of low-density lipoprotein cholesterol (LDL-C), triglyceride (TG), and the reduction in high-density lipoprotein cholesterol (HDL-C) level), is one of the major risk factor related to CVD incidences [3].

The alteration of gut microbiota is closely associated with several ill-health conditions. High fatand sugar-containing diet, and low dietary fiber have a negative impact on the gastrointestinal system [4]. Several studies revealed the link between gut microbiota and CVD incidences and progress $[5,6]$. Lower abundance of Bacteroidetes, higher abundance of Lactobacillales, Enterobacteriaceae, Streptococcus spp., and increased Firmicutes/Bacteroidetes ratio are associated with CVD [6]. The healthy dietary preference (rich in vegetables, fibers, and low consumption of meat and refined food products) could improve gut health and reduce the risk of CVD.

Probiotics are live microbes that exhibit beneficial effect on human health when consumed in a suitable amount [7]. Microbes that possess several health beneficial effects are termed as probiotics 
after evaluating the safety and stability of the strain based on the standard regulations developed by the Food and Agriculture Organization of the United Nations and the World Health Organization Expert Consultation on Evaluation of Health and Nutritional Properties of Probiotics [8-10]. The most commonly used probiotics are Bifidobacteria and lactic acid bacteria. Other reported probiotics include strains of Saccharomyces, Streptococcus, Pediococcus, Leuconostoc, Enterococcus, and Bacillus [11].

Probiotics are the potent players involved in the regulation of gut microbiota, thereby, it is closely associated with human health and diseases state. Probiotics and probiotic-based fermented foods are associated with the improvement of the health status of people who suffered from metabolic disorders [12,13], inflammatory bowel diseases [11], antibiotic-associated diarrhea [14], menopausal symptoms [15], and skin diseases [16]. The role of probiotics in mental health and cognitive improvement [17] and the aging process [18] have been reported. The health benefits of probiotic supplementation are attributed to their ability to maintain the equilibrium of gut microbiota and immune system via the production of bacteriocins-like substances, short-chain fatty acids, and some neurotransmitters like $\gamma$-aminobutyric acid $[19,20]$.

Several in vitro and animal studies reported the cholesterol-lowering activity of probiotics [21-23]. The current review focused on the outcomes of recent human studies concerning the cholesterol-lowering property of probiotics. Studies based on the meta-analysis of probiotics supplementation and lipid profile changes and non-significant outcome of clinical trials were also summarized. The literature was collected from Scopus, PubMed, and Web of Science using the keywords "probiotics" and "cholesterol" without any chronological restrictions. The relevant scientific papers were selected based on the studies with human subjects and also published (at least abstract with clear content) in the English language for the preparation of the manuscript.

Factors Affecting the Cholesterol Levels in Human

Age and gender play a role in affecting cholesterol levels. Cholesterol levels tend to increase in older people. Total cholesterol and LDL-C levels may tend to increase in women after menopause stage. Heredity may play a role in affecting cholesterol levels. Lack of physical activity is one of the major causes of overweight and obesity, which affects the cholesterol level resulting increased total cholesterol, LDL-C, TG, and decreased HDL-C levels. Therefore, weight management should be focused on healthy lifestyle (healthy diet and physical activity) to manage the cholesterol levels and to reduce the risk of CVDs. Consumption of probiotics may have a positive effect on managing the cholesterol levels.

\section{Impact of Probiotic Supplementation on the Lipid Profile of the Human Subjects}

\subsection{Hypercholesterolemic Subjects}

Cavallini et al. [24] studied the effect of probiotics (Enterococcus faecium CRL 183 and Lactobacillus helveticus 416) fermented soy product containing isoflavone on the lipid profile of moderately hypercholesterolemic male subjects. The supplementation of soy product (equivalent of $10^{10} \mathrm{CFU}$ of probiotic strain) with $50 \mathrm{mg}$ isoflavone per day for 42 days significantly improved the total cholesterol (TC), LDL-C (low-density lipoprotein-cholesterol) and electronegative LDL content in the subjects while the level of HDL-C (high-density lipoprotein-cholesterol) was unaffected and the level of fibrinogen and C-reactive protein levels were not enhanced. The results suggested that the consumption of probiotic soy product with isoflavone improved the cardiovascular risk factors in hypercholesterolemic subjects [24].

A 12-week supplementation of a mixture of L. plantarum strains (CECT 7528, CECT 7529, CECT 7527; $10^{10} \mathrm{CFU} /$ day) significantly increased the level of HDL-C and reduced LDL-C, TC, triglycerides (TG), LDL-C/HDL-C ratio, and oxidized LDL levels in hypercholesterolemic subjects. The results revealed that probiotics could be used for hypercholesterolemia treatment [25].

The dyslipidemic children were supplemented with a mixture of Bifidobacterium strains (B. animalis lactis MB 2409, B. longum BL04, and B. bifidum MB 109B) for three months and their diet was monitored. After the intervention, the changes in lipid profile were measured. The concentration of serum level TC $(222.8 \pm 23.2$ to $211.9 \pm 27.3 \mathrm{mg} / \mathrm{dL})$, HDL-C $(55.8 \pm 12.2$ to $60.7 \pm 14.2 \mathrm{mg} / \mathrm{dL}), \mathrm{TG}(99.0 \pm 61.7$ 
to $79.5 \pm 34.5 \mathrm{mg} / \mathrm{dL})$, and LDL-C $(147.2 \pm 21.9$ to $135.3 \pm 24.2 \mathrm{mg} / \mathrm{dL})$ were significantly improved after three months of probiotic supplementation when compared to the baseline values. The TC and LDL-C levels were notably reduced in the probiotic group compared to that of the placebo. The results suggested that the supplementation of probiotics with dietary restriction help to improve the lipid profile in dyslipidemic children [26].

The consumption of single probiotic strain (E. faecium M-74; $2 \times 10^{9} \mathrm{CFU} /$ day) and selenium $(50 \mu \mathrm{g})$ for one year did not alter the level of HDL-C and TG, while it significantly reduced the TC, and LDL-C in elderly people compared to baseline and to that of the placebo. The study results recommend that probiotics are promising therapeutic agents for several human ill-health conditions [27].

The intervention of probiotic capsule containing L. acidophilus and B. bifidum ( $10^{9} \mathrm{CFU} / \mathrm{capsule}$; three capsule/day) for six weeks significantly reduced the TC and LDL-C level in hypercholesterolemic patients. There was no change in TG and blood sugar levels of the patients. The level of HDL-C was significantly reduced during the study period. However, the probiotic supplements improved the cholesterol profile, and the HDL-C content also reduced. The authors claimed that L. acidophilus and B. bifidum have the potential to lower cholesterol in hypercholesterolemic patients [28].

A significant level of reduction (15.5\%) in remnant lipoprotein particle (RLP-P) content was observed in the hypercholesterolemic patients, who had probiotic supplementation (Saccharomyces cerevisiae var. boulardii CNCM I-1079) for eight weeks. The consumption of four probiotic capsules $\left(1.4 \times 10^{9} \mathrm{CFU} / \mathrm{capsule}\right)$ twice per day does not alter the TC, LDL-C, very low-density lipoprotein-particle (VLDL-P), HDL-C, TG level, insulin, and representative cardiovascular markers, significantly, but the notable level of RLP-P reduction was recorded after the experimental period. The results suggested that CNCM I-1079 supplementation could be used as an adjuvant for preventing and treating coronary artery disease [29].

\subsection{Healthy Subjects}

The supplementation of a milk-based fruit drink containing probiotic strain L. rhamnosus GG $\left(6.2 \times 10^{7}\right.$ $\mathrm{CFU} / \mathrm{ml} ; 250 \mathrm{ml}$ per day for three weeks) positively altered the global lipid profile in healthy volunteers. Particularly, the level of sphingomyelins, lysophosphatidylcholines, and glycerophosphatidylcholines were reduced after probiotic supplementation while triacylglycerols content was increased when compared to baseline and to that of the placebo. The study also revealed the association of inflammatory cytokines and lipid profile changes upon probiotic intervention. The results proved that the intervention of L. rhamnosus GG improves the lipid profile in healthy subjects [30].

The supplementation of $30 \mathrm{~g}$ of probiotic cheese containing L. acidophilus LA5 and B. lactis BB12 (each $5 \times 10^{6} \mathrm{CFU}$ ) with or without $30 \mathrm{~g}$ of chicory root extract significantly reduced the TC and LDL-C and increased the HDL-C content in healthy volunteers in seven weeks of the experimental period. The level of TG was reduced at a notable level in group supplemented with probiotics and chicory root extract. There was no change in anthropometric measurements of the volunteers after the experimental period when compared to baseline measurements. The study claimed that the use of probiotic cheese containing LA5 and BB12 along with chicory root extract might be used to treat and prevent the dyslipidemic condition [31].

\subsection{Diabetes Patients}

The consumption of probiotic yogurt (300 g per day) containing L. acidophilus La5 $\left(\sim 4.14 \times 10^{6}\right.$ $\mathrm{CFU} / \mathrm{g})$ and B. lactis Bb12 $\left(\sim 3.61 \times 10^{6} \mathrm{CFU} / \mathrm{g}\right)$ for six weeks significantly improved the lipid profile of type 2 diabetes mellitus (T2D) patients. Specifically, the level of TC, LDL-C, and ratio of LDL-C:HDL-C and TC:HDL-C were reduced significantly when compared to baseline and to that of the placebo control. There was no change in HDL-C and TG content in studied subjects. The results suggested that the regular consumption of probiotic yogurt could improve the cholesterol level of T2D patients [32].

The supplementation of probiotic capsule containing L. acidophilus, L. casei, and B. bifidum (each $2 \times 10^{9} \mathrm{CFU} / \mathrm{g}$ ) for six weeks reduced the TG and VLDL-C content in gestational diabetic (GD) patients 
while no changes were observed in LDL-C, HDL-C, and TC. The probiotic supplementation improved the serum insulin, plasma glucose level, homeostasis model assessment for insulin resistance (HOMA-IR), and insulin sensitivity when compared to that of the placebo. The consumption of a probiotic capsule enhanced the glycemic control and slightly improved the lipid profile of GD patients [33].

The consumption of fermented milk containing B. animalis subsp. lactis BB-12 and L. acidophilus La-5 (each $10^{9} \mathrm{CFU} ; 120 \mathrm{~g}$ of fermented milk) for six weeks significantly reduced the LDL-C and TC content in T2D patients. Additionally, the probiotic group showed reduced inflammatory cytokines level and metabolic parameters such as HOMA-IR, HbA1c, fructosamine, and fasting blood glucose (FBG). The study concluded that the probiotic consumption amended the glycemic control, inflammatory system, and lipid profile in T2D subjects [34].

The daily consumption of $200 \mathrm{~mL}$ of fermented soymilk containing $2 \times 10^{7} \mathrm{CFU} / \mathrm{mL}$ of L. plantarum A7 for eight weeks significantly reduced the TC, TG, LDL-C, and non-HDL-C in T2D patients while HDL-C content was not altered when compared to baseline and to that of the control group. The serum genistein and estimated glomerular filtration rate (eGFR) values were increased in the probiotic soymilk-supplemented group when compared to the non-probiotic soymilk group. The results suggested that L. plantarum A7 fermented soymilk showed a favorable impact on glomerular function and lipid profile of T2D subjects [35].

The supplementation of $6 \mathrm{~g} /$ day of probiotic preparation made with L. acidophilus, B. bifidum, B. lactis, and B. longum (each $1.5 \times 10^{9} \mathrm{CFU}$ ) for 24 weeks reduced the occurrence of low-HDL-C and increased the HDL-C content when compared to the placebo control. The parameters associated with hyperglycemia, hypertension, and metabolic syndrome have also been reduced significantly in the probiotic group compared to that of the placebo control group [36].

The consumption of multi-species probiotic preparation (L. acidophilus ZT-L1, L. reuteri ZT-Lre, L. fermentum ZT-L3, and B. bifidum ZT-B1; $2 \times 10^{9}$ CFU/day) for 12 weeks significantly reduced the TG, TC:HDL-C ratio, and increased the HDL-C level in diabetic nephropathy (DN) patients compared to that of the placebo control. The increase in insulin sensitivity and plasma total glutathione, and decrease in FBG, HOMA-IR values, and malondialdehyde, high-sensitive C-reactive protein were observed in the probiotic-treated group. The results suggested that probiotic consumption improved the cardiovascular diseases risk factors in DN patients [37].

The supplementation of Ecologic ${ }^{\circledR}$ Barrier (multi-strain probiotic preparation containing B. bifidum W23, B. lactis W51, B. lactis W52, L. acidophilus W37, L. brevis W63, L. casei W56, L. salivarius W24, Lactococcus lactis W19, and Lactococcus lactis W58; dosage: two doses per day) for six months reduced the TG, TC, LDL-C, and TC:HDL-C ratio values significantly when compared to the placebo and baseline values. Ecologic ${ }^{\circledR}$ Barrier supplementation also reduced the FBG, insulin, HOMA-IR values, and inflammatory cytokines level in T2D patients. The results suggested that multi-strain probiotic preparation could be an adjuvant therapeutic agent to improve diabetic and cardiovascular-associated metabolic parameters [38].

\subsection{Other Subjects}

The supplementation of Ecologic ${ }^{\circledR}$ Barrier $\left(2.5 \times 10^{9}\right.$ or $1 \times 10^{10} \mathrm{CFU} /$ day $)$ for 12 weeks improved the TG and LDL-C content and other metabolic and cardiovascular disease parameters in obese postmenopausal women [39].

The supplementation of $B$. breve B-3 capsules $\left(2 \times 10^{10} \mathrm{CFU} /\right.$ day) for 12 weeks slightly reduced the TG and improved the HDL-C content in pre-obese subjects, but the changes are not significant when compared to baseline values. However, the probiotic supplementation reduced the body fat in healthy pre-obese subjects; and the lipid profile was not improved significantly [40]. Similarly, L. gasseri BNR17 supplementation $\left(10^{9}\right.$ or $10^{10} \mathrm{CFU} /$ day) for 12 weeks reduced the visceral fat mass in obese subjects, but the changes in the TC, LDL-C, HDL-C, and TG were not significant when compared to the placebo control [41]. The results have been summarized in Table 1. 
Table 1. Impact of probiotic supplementation on lipid profile of human volunteers.

\begin{tabular}{|c|c|c|c|c|c|c|c|}
\hline Study & Subjects & Diet & Intervention & Dosage & Duration & Findings & Ref. \\
\hline RPCDB & $\begin{array}{l}\text { Healthy male individuals } \\
\text { with moderate } \\
\text { hypercholesterolemia; } n= \\
\text { 49; Age = } 37 \text { to } 57 \text { years }\end{array}$ & $\begin{array}{l}\text { No changes in the usual } \\
\text { diet }\end{array}$ & $\begin{array}{l}\text { Fermented soy product } \\
\text { containing Enterococcus } \\
\text { faecium CRL 183, and } \\
\text { Lactobacillus helveticus } \\
416 \text { and isoflavone }\end{array}$ & $\begin{array}{l}200 \text { ml per day }\left(10^{10}\right. \\
\text { CFU/ day) }\end{array}$ & 42 days & $\begin{array}{l}\text { - Improved the TC, LDL-C and } \\
\text { electronegative LDL content } \\
\text { - } \\
\text { Retained the HDL }\end{array}$ & [24] \\
\hline RPCDB & $\begin{array}{c}\text { Adults with } \\
\text { hypercholesterolemia; } n= \\
60 \text { (34 male, } 26 \text { female); Age } \\
=18 \text { to } 65 \text { years }\end{array}$ & No specific diet & $\begin{array}{l}\text { Lactobacillus plantarum (3 } \\
\text { strains) }\end{array}$ & $\begin{array}{l}100 \mathrm{mg} \text { of the probiotic } \\
\text { mixture }\left(10^{10} \mathrm{CFU}\right. \\
\text { during production) per } \\
\text { capsule; } 1 \text { capsule/ day }\end{array}$ & 12 weeks & $\begin{array}{ll} & -1 \text { LDL-C } \\
: & \downarrow \text { TC, TG } \\
: & \downarrow \text { LDL-C/HDL-C ratio } \\
: & \downarrow \text { Oxidized LDL } \\
- & \uparrow \text { HDL-C }\end{array}$ & [25] \\
\hline RPCDB & $\begin{array}{l}\text { Dyslipidemic children; Age } \\
\quad=6 \text { to } 18 \text { years }\end{array}$ & $\begin{array}{l}\text { STEP } 1 \text { diet (normal } \\
\text { caloric diet) }\end{array}$ & $\begin{array}{c}\text { Bifidobacterium animalis } \\
\text { subsp. lactis MB 2409, } B \text {. } \\
\text { bifidum MB 109B, and } B \text {. } \\
\text { longum BL04 }\end{array}$ & $\begin{array}{l}3 \text { strains (each } 10^{9} \mathrm{CFU} \text { ) } \\
\text { within one capsule/ day }\end{array}$ & 3 months & $\begin{array}{ll}- & \downarrow \text { LDL-C } \\
- & \downarrow \text { TC, TG } \\
- & \uparrow \text { HDL-C }\end{array}$ & [26] \\
\hline RPCDB & $\begin{array}{c}\text { Elderly people; } n=38 \text { ( } 7 \\
\text { male, } 31 \text { female); Age = } 70 \\
\text { to } 80 \text { years }\end{array}$ & No specific diet & $\begin{array}{l}\text { E. faecium M-74 and } \\
\text { selenium }\end{array}$ & $\begin{array}{c}2 \times 10^{9} \mathrm{CFU} \text { of probiotic } \\
\text { and } 50 \mu \mathrm{g} \text { selenium per } \\
\text { capsule/ day }\end{array}$ & 1 year & $\begin{array}{ll}\text { - } & \downarrow \text { TC } \\
: & \downarrow \text { LDL-C } \\
\text { - No change in HDL-C, and TG }\end{array}$ & [27] \\
\hline RPCDB & $\begin{array}{c}\text { Hypercholesterolemic } \\
\text { patients; } n=64 \text { (male); Age } \\
\quad=40 \text { to } 60 \text { years }\end{array}$ & $\begin{array}{l}\text { Minimum calorie diet } \\
\text { with minimal intake of } \\
\text { lipid }\end{array}$ & $\begin{array}{l}\text { L. acidophilus and } B . \\
\text { bifidum }\end{array}$ & $\begin{array}{l}3 \text { capsule/day; } \\
\text { Each strain } 10^{9} \\
\text { CFU/capsule }\end{array}$ & 6 weeks & $\begin{array}{ll}- & \downarrow \text { TC } \\
: & \downarrow \text { LDL-C } \\
- & \downarrow \text { HDL-C }\end{array}$ & [28] \\
\hline $\begin{array}{l}\text { Single-Arm, } \\
\text { Open-Label Study }\end{array}$ & $\begin{array}{c}\text { Healthy adults with } \\
\text { hypercholesterolemia; } n= \\
11 \text { (10 male, } 1 \text { female); Age } \\
=21 \text { to } 69 \text { years }\end{array}$ & $\begin{array}{l}\text { No changes in the usual } \\
\text { diet }\end{array}$ & $\begin{array}{c}\text { Saccharomyces cerevisiae } \\
\text { var. boulardii CNCM } \\
\text { I-1079 }\end{array}$ & $\begin{array}{l}4 \text { capsules twice a day; } \\
1.4 \times 10^{10} \mathrm{CFU} / \text { capsule }\end{array}$ & 8 weeks & - $\quad \downarrow$ Remnant lipoprotein particle & [29] \\
\hline RPCDB & $\begin{array}{c}\text { Healthy people; } n=26(12 \\
\text { male, } 14 \text { female); Age }=23 \\
\text { to } 55 \text { years }\end{array}$ & No specific diet & L. rhamnosus GG & $\begin{array}{c}250 \mathrm{ml} \text { probiotic } \\
\text { drink/day }\left(6.2 \times 10^{7}\right. \\
\text { CFU } / \mathrm{ml})\end{array}$ & 3 weeks & $\begin{array}{ll}\text { - } & \downarrow \text { Lysophosphatidylcholines } \\
\text { - } & \downarrow \text { Sphingomyelins } \\
& \\
\text { - } & \downarrow \text { Glycerophosphatidylcholines } \\
& \uparrow \text { Triacylglycerols }\end{array}$ & [30] \\
\hline
\end{tabular}


Table 1. Cont

\begin{tabular}{|c|c|c|c|c|c|c|c|}
\hline Study & Subjects & Diet & Intervention & Dosage & Duration & Findings & Ref. \\
\hline RPCDB & $\begin{array}{c}\text { Healthy people; } n=180 \text { (90 } \\
\text { male, } 90 \text { female); Age }=18 \\
\text { to } 65 \text { years }\end{array}$ & $\begin{array}{l}\text { Consumption of low-fat } \\
\text { milk for a week before } \\
\text { the trial begins }\end{array}$ & $\begin{array}{l}\text { L. acidophilus LA5 and } B . \\
\text { lactis BB12 + chicory } \\
\text { root extract }\end{array}$ & $\begin{array}{l}30 \mathrm{~g} \text { probiotic cheese } \\
\text { (each strain } 5 \times 10^{6} \\
\text { CFU) and } 30 \mathrm{~g} \text { of } \\
\text { chicory root extract }\end{array}$ & 7 weeks & $\begin{array}{ll}- & \downarrow \text { TC } \\
- & \downarrow \text { LDL-C } \\
- & \downarrow \text { TG } \\
- & \uparrow \text { HDL-C }\end{array}$ & [31] \\
\hline RPCDB & $\begin{array}{l}\text { Individuals with T2D; } n= \\
60 \text { (23 male, } 37 \text { female); Age } \\
\quad=30 \text { to } 60 \text { years }\end{array}$ & $\begin{array}{l}\text { No changes in the usual } \\
\text { diet }\end{array}$ & $\begin{array}{c}\text { Probiotic yogurt with } L . \\
\text { acidophilus, } \\
\text { La5 and B. lactis Bb12 }\end{array}$ & $300 \mathrm{~g}$ of yogurt per day & 6 weeks & $\begin{array}{ll}- & \downarrow \text { TC } \\
- & \downarrow \text { LDL-C } \\
- & \downarrow \text { LDL-C:HDL-C ratio } \\
- & \downarrow \text { TC:HDL-C ratio }\end{array}$ & [32] \\
\hline RPCDB & $\begin{array}{c}\text { Gestational diabetic } \\
\text { patients; } n=60 ; \mathrm{Age}=18 \text { to } \\
40 \text { years }\end{array}$ & $\begin{array}{l}\text { No changes in the usual } \\
\text { diet }\end{array}$ & $\begin{array}{l}\text { L. acidophilus, L. casei } \\
\text { and B. bifidum }\end{array}$ & $\begin{array}{l}\text { One capsule (Each strain } \\
2 \times 10^{9} \mathrm{CFU} / \mathrm{g} \text { ) per day }\end{array}$ & 6 weeks & $\begin{array}{ll}- & \downarrow \text { VLDL } \\
\text { - } & \downarrow \text { TG } \\
- & \text { No change in HDL-C }\end{array}$ & [33] \\
\hline RPCDB & $\begin{array}{l}\text { Individuals with T2D; } n= \\
\begin{array}{c}45 \text { (26 male, } 19 \text { female); Age } \\
=35 \text { to } 60 \text { years }\end{array}\end{array}$ & $\begin{array}{l}\text { No changes in the usual } \\
\text { diet }\end{array}$ & $\begin{array}{l}\text { Fermented milk with } L \text {. } \\
\text { acidophilus La-5 and } B \text {. } \\
\text { animalis subsp. lactis } \\
\text { BB-12 }\end{array}$ & $\begin{array}{c}120 \mathrm{~g} \text { of fermented milk } \\
\text { per day; (Each strain } 10^{9} \\
\text { CFU/day) }\end{array}$ & 6 weeks & $\begin{array}{ll}\bullet & \downarrow \text { TC } \\
\bullet & \downarrow \text { LDL-C }\end{array}$ & [34] \\
\hline RPCDB & $\begin{array}{c}\text { T2D patients; } n=40(19 \\
\text { male, } 21 \text { female); Age }=40 \\
\text { to } 70 \text { years }\end{array}$ & $\begin{array}{c}\text { Diet (consists of } 0.8 \mathrm{~g} / \mathrm{kg} \\
\text { protein, } 2 \mathrm{~g} \text { potassium, } \\
1.5 \mathrm{~g} \text { phosphorus, and } 2 \\
\mathrm{~g} \text { sodium) }\end{array}$ & $\begin{array}{l}\text { Soy milk containing } L \text {. } \\
\text { plantarum } \mathrm{A} 7\end{array}$ & $\begin{array}{c}200 \mathrm{ml} \text { of probiotic soy } \\
\mathrm{milk} / \text { day; } 2 \times 10^{7} \\
\text { CFU } / \mathrm{ml}\end{array}$ & 8 weeks & $\begin{array}{ll}\text { - } & \downarrow \text { TC } \\
\dot{1} & \downarrow \text { LDL-C } \\
: & \downarrow \text { non-HDL-C } \\
: & \downarrow \text { TG } \\
\text { - } & \text { No change in HDL-C }\end{array}$ & [35] \\
\hline RPCDB & $\begin{array}{l}\text { Pre-diabetic subjects; } n= \\
120 \text { ( } 50 \text { male, } 70 \text { female); } \\
\text { Age }=35 \text { to } 70 \text { years }\end{array}$ & $\begin{array}{l}\text { No changes in the usual } \\
\text { diet }\end{array}$ & $\begin{array}{l}\text { L. acidophilus, B. bifidum, } \\
\text { B. lactis, and B. longum }\end{array}$ & $\begin{array}{c}6 \text { g per day (Each strain } \\
1.5 \times 10^{9} \mathrm{CFU} / \text { day) }\end{array}$ & 24 weeks & $\begin{array}{ll}\text { - } & \downarrow \text { low HDL-C } \\
& \uparrow \text { HDL-C }\end{array}$ & [36] \\
\hline RPCDB & $\begin{array}{c}\text { Diabetic nephropathy } \\
\text { patients; } n=60 ; \text { Age }=45 \text { to } \\
85 \text { years }\end{array}$ & $\begin{array}{l}\text { No changes in the usual } \\
\text { diet }\end{array}$ & $\begin{array}{l}\text { L. acidophilus ZT-L1, } L \text {. } \\
\text { reuteri } \mathrm{ZT}-\mathrm{Lre}, L \text {. } \\
\text { fermentum } \mathrm{ZT-L3} \text { and } B . \\
\text { bifidum } \mathrm{ZT}-\mathrm{B} 1\end{array}$ & $\begin{array}{c}8 \times 10^{9} \mathrm{CFU} / \text { day (Each } \\
\text { strain } 2 \times 10^{9} \mathrm{CFU} / \text { day) }\end{array}$ & 12 weeks & $\begin{array}{ll}- & \downarrow \text { TG } \\
- & \downarrow \text { TC:HDL-C ratio } \\
- & \uparrow \text { HDL-C }\end{array}$ & [37] \\
\hline
\end{tabular}


Table 1. Cont.

\begin{tabular}{|c|c|c|c|c|c|c|c|}
\hline Study & Subjects & Diet & Intervention & Dosage & Duration & Findings & Ref. \\
\hline RPCDB & $\begin{array}{c}\text { T2D patients; } n=40(19 \\
\text { male, } 21 \text { female); Age = } 40 \\
\text { to } 70 \text { years }\end{array}$ & $\begin{array}{c}\text { Diet (consists of } 0.8 \mathrm{~g} / \mathrm{kg} \\
\text { protein, } 2 \mathrm{~g} \text { potassium, } \\
1.5 \mathrm{~g} \text { phosphorus, and } 2 \\
\text { g sodium) }\end{array}$ & $\begin{array}{l}\text { Soy milk containing } L \text {. } \\
\text { plantarum } \mathrm{A} 7\end{array}$ & $\begin{array}{c}200 \mathrm{ml} \text { of probiotic soy } \\
\mathrm{milk} / \text { day; } 2 \times 10^{7} \\
\text { CFU } / \mathrm{ml}\end{array}$ & 8 weeks & $\begin{array}{ll}\text { - } & \downarrow \text { TC } \\
: & \downarrow \text { LDL-C } \\
\dot{ } & \downarrow \text { non-HDL-C } \\
\text { - } & \downarrow \text { TG } \\
& \text { No change in HDL-C }\end{array}$ & [35] \\
\hline RPCDB & $\begin{array}{l}\text { Pre-diabetic subjects; } n= \\
120(50 \text { male, } 70 \text { female); } \\
\text { Age }=35 \text { to } 70 \text { years }\end{array}$ & $\begin{array}{l}\text { No changes in the usual } \\
\text { diet }\end{array}$ & $\begin{array}{l}\text { L. acidophilus, B. bifidum, } \\
\text { B. lactis, and B. longum }\end{array}$ & $\begin{array}{l}6 \text { g per day (Each strain } \\
1.5 \times 10^{9} \text { CFU/day) }\end{array}$ & 24 weeks & $\begin{array}{l}-\quad \downarrow \text { low HDL-C } \\
-\quad \uparrow \text { HDL-C }\end{array}$ & [36] \\
\hline RPCDB & $\begin{array}{c}\text { Diabetic nephropathy } \\
\text { patients; } n=60 ; \text { Age }=45 \text { to } \\
85 \text { years }\end{array}$ & $\begin{array}{l}\text { No changes in the usual } \\
\text { diet }\end{array}$ & $\begin{array}{l}\text { L. acidophilus ZT-L1, } L . \\
\text { reuteri ZT-Lre, } L . \\
\text { fermentum } \text { ZT-L3 and } B . \\
\text { bifidum ZT-B1 }\end{array}$ & $\begin{array}{l}8 \times 10^{9} \mathrm{CFU} / \text { day (Each } \\
\text { strain } 2 \times 10^{9} \mathrm{CFU} / \text { day) }\end{array}$ & 12 weeks & $\begin{array}{ll}- & \downarrow \text { TG } \\
\bullet & \downarrow \text { TC:HDL-C ratio } \\
- & \uparrow \text { HDL-C }\end{array}$ & [37] \\
\hline RPCDB & $\begin{array}{c}\text { T2D patients; } n=61(26 \\
\text { male, } 35 \text { female); Age }=35 \\
\text { to } 70 \text { years }\end{array}$ & $\begin{array}{c}\text { No changes in the usual } \\
\text { diet }\end{array}$ & $\begin{array}{l}\text { B. bifidum W23, B. lactis } \\
\text { W51, and W52, L. } \\
\text { acidophilus W37, L. brevis } \\
\text { W63, } \\
\text { L. casei W56, L. salivarius } \\
\text { W24, Lactococcus lactis } \\
\text { W19 and W58 }\end{array}$ & $\begin{array}{l}2 \mathrm{~g} \text { of the probiotic } \\
\text { mixture }\left(2.5 \times 10^{9}\right. \\
\text { CFU/g) per day }\end{array}$ & 6 months & $\begin{array}{ll}\bullet & \downarrow \text { TG } \\
\bullet & \downarrow \text { TC } \\
\bullet & \downarrow \text { LDL-C } \\
\bullet & \downarrow \text { TC:HDL-C ratio }\end{array}$ & [38] \\
\hline RPCDB & $\begin{array}{c}\text { Obese postmenopausal } \\
\text { women; } n=71 ; \text { Age }=45 \text { to } \\
70 \text { years }\end{array}$ & $\begin{array}{l}\text { No changes in the usual } \\
\text { diet }\end{array}$ & $\begin{array}{l}\text { B. bifidum W23, B. lactis } \\
\text { W51, and W52, L. } \\
\text { acidophilus W37, L. brevis } \\
\text { W63, L. casei W56, } \\
\text { L. salivarius W24, } \\
\text { Lactococcus lactis W19 } \\
\text { and W58 }\end{array}$ & $\begin{array}{l}2 \mathrm{~g} \text { of the probiotic } \\
\text { mixture (high dose: } 1 \times \\
10^{10} \mathrm{CFU} \text {; low dose: } 2.5 \\
\times 10^{9} \mathrm{CFU} \text { ) per day }\end{array}$ & 12 weeks & $\begin{array}{ll}\text { - } & \text { In both High dose and low } \\
& \text { dose group } \\
\text { - } & \downarrow \text { TG } \\
\text { - } & \downarrow \text { TC } \\
\text { - } & \downarrow \text { LDL-C }\end{array}$ & [39] \\
\hline RPCDB & $\begin{array}{l}\text { Healthy pre-obese adults; } n \\
=80 \text { (74 male, } 6 \text { female); } \\
\text { Age }=35 \text { to } 56 \text { years }\end{array}$ & No changes in usual diet & B. breve $B-3$ & $\begin{array}{l}2 \text { capsule per day; } \\
10 \times 10^{9} \mathrm{CFU} \text { per } \\
\text { capsule }\end{array}$ & 12 weeks & $\begin{array}{ll}\text { - } & \downarrow \mathrm{TG} \\
& \text { Improved HDL }\end{array}$ & [40] \\
\hline RPCDB & $\begin{array}{c}\text { Obese adults; } n=90(27 \\
\text { male, } 63 \text { female); Age = } 20 \\
\text { to } 75 \text { years }\end{array}$ & $\begin{array}{c}\text { As per dietitian } \\
\text { instruction, subjects } \\
\text { reduced } 200 \text { kcal from } \\
\text { their usual diet every } \\
\text { day }\end{array}$ & $\begin{array}{l}\text { Lactobacillus gasseri } \\
\text { BNR17 }\end{array}$ & $\begin{array}{l}2 \text { capsules (high dose: } 1 \\
\times 10^{10} \mathrm{CFU} \text {; low dose: } 1 \\
\times 10^{9} \mathrm{CFU} \text { ) per day; } 400 \\
\quad \text { mg per capsule }\end{array}$ & 12 weeks & $\begin{array}{l}\text { - No significant changes in TC, } \\
\text { TG, and LDL-C }\end{array}$ & [41] \\
\hline
\end{tabular}

CDB: Randomized, placebo-controlled, double-blind study, TC: Total cholesterol, LDL-C: Low-density lipoprotein-cholesterol; HDL-C: High-density lipoprotein-cholesterol; TG: Triglycerides; T2D: Type 2 diabetes mellitus; VLDL: Very low-density lipoprotein-cholesterol. 


\section{Meta-Analysis Studies}

Several meta-analysis studies have been published based on the effect of probiotic supplementation on the lipid profile of human subjects. The probiotic supplementation (both in the form of freeze-dried powder, fermented products) significantly reduced TC and LDL-C in hypercholesterolemic subjects while no significant changes were observed in TG and HDL-C content [42-46]. The sub-group analysis of clinical trials suggested that the long-term consumption of probiotic exhibited more beneficial effects on the lipid profile of the subjects [44]. A recent study reported that intervention of probiotics significantly reduced the TC when compared to the TC of the control group, and also stated that specific probiotic strains (B. lactis and L. acidophilus; L. plantarum) significantly reduced the TC [47]. Another recent study suggested that the probiotic preparations containing Lactobacillus and Bifidobacterium could reduce the LDL-C content in metabolic syndrome patients without improving the TC and HDL-C content [48].

Probiotic consumption improved the TC and HDL-C content in non-alcoholic fatty liver disease (NAFLD) subjects, but no changes were found to be observed in the level of LDL-C. The study claimed that there were no sufficient studies on the impact of probiotic consumption on NAFLD to confirm the beneficial role of probiotics [49].

The probiotic interventions significantly improved the lipid profile (reduced the TC, LDL-C, and TG) of T2D patients along with the glucose homeostasis effectively [50-52].

Collectively, the results of meta-analysis revealed that the supplementation of probiotics might improve the lipid profile of the human subjects. The efficiency of the probiotic intervention hinges on several factors like dosage, duration of the treatment, combination of the probiotics strains, strain quality, host metabolic activities, host-microbiome, etc. Thus, all the probiotic formulations are effective in conferring the beneficial effects on the host system. The non-significant outcomes of probiotic intervention studies are detailed in the following section.

\section{Effect of Probiotics Supplementation on Lipid Profile: Non-Significant Outcomes}

The consumption of L. acidophilus $\left(9 \times 10^{10} \mathrm{CFU} /\right.$ day for six weeks), B. animalis subsp. lactis BB-12 ${ }^{\circledR}\left(3.16 \times 10^{9}\right.$ CFU/day for four weeks), probiotic yogurt containing both L. acidophilus and BB-12 ${ }^{\circledR}$ $\left(3.0 \times 10^{9} \mathrm{CFU} /\right.$ day for seven days), and L. acidophilus and B. longum (each $10^{10} \mathrm{CFU} /$ day for two months) did not amend the lipid profile in healthy human subjects [53-56].

Recently, Culpepper et al. [57] reported that the supplementation of B. subtilis R0179 $\left(2.5 \times 10^{9}\right.$ CFU), B. animalis subsp. lactis B94 $\left(5 \times 10^{9} \mathrm{CFU}\right)$ for six weeks does not have any influential effect on the lipid profile of healthy obese subjects.

A multi-genus and multi-species probiotic formula (L. acidophilus, L. casei, L. rhamnosus, L. bulgaricus, B. breve, B. longum, and Streptococcus thermophilus) supplementation for eight weeks showed no improvement in the lipid profile of T2D patients [58]. Mahboobi et al. [59] noticed that the consumption of a multi-species probiotic capsule did not alter the TC, LDL-C, HDL-C, or TG values in pre-diabetic subjects when compared to baseline and to that of the placebo control. Similarly, the supplementation of probiotic (Lactobacillus spp., Bifidobacterium spp., S. thermophilus) or synbiotic formulation (probiotics and fructo-oligosaccharide) did not amend the lipid profile of T2D patients $[60,61]$.

A multi-species probiotic preparation containing four Lactobacillus spp. (L. acidophilus, L. bulgaricus, L. bifidum, and L. casei) did not improve the lipid profile in T2D patients. Only a non-significant increase in HDL-C level was observed in the experimental subjects [62]. Similarly, 12 weeks of the randomized controlled clinical study suggested that the Ecologic ${ }^{\circledR}$ Barrier supplementation did not improve the lipid profile in T2D patients [63]. 


\section{Opinion on the Hypocholesterolemic Effect of Reviewed Probiotics}

Based on the randomized, placebo-controlled, double-blind studies [24-41] reviewed in the present article, the hypocholesterolemic effect of the probiotics was not significantly influenced by the diet. Studies reported based on the intervention of single-strain probiotic (E. faecium M-74 along with selenium [27]; Saccharomyces cerevisiae var. boulardii CNCM I-1079 [29]; L. rhamnosus GG [30]; Soy milk containing L. plantarum A7 [35]) preparation showed significant hypocholesterolemic effect when compared to the study reported with the intervention of single-strain probiotics (B. breve B-3 [40]; Lactobacillus gasseri BNR17 [41]) preparation; whereas intervention of single-strain probiotics (L. acidophilus [53]; B. animalis subsp. lactis BB-12 [54]) preparation exhibited no beneficial effect on the lipid profile of the studied subjects. Therefore, the level of improving lipid profile is strain-specific and might depend on the dosage and duration of the intervention.

Studies based on the intervention of multi-genus, multi-species, multi-strain (strains of same species) probiotic preparation has been reported with positive effect on lipid profile [24-26,28,31-34,36-39,47,48], while several studies reported no effect of multi-genus and multi-species probiotic intervention on the lipid profile [55-63]. Even though intervention of Ecologic ${ }^{\circledR}$ Barrier (B. bifidum W23, B. lactis W51, B. lactis W52, L. acidophilus W37, L. brevis W63, L. casei W56, L. salivarius W24, Lactococcus lactis W19 and W58) exhibit hypocholesterolemic effect on different subjects (individuals with T2D [38]; obese postmenopausal women [39]) with different intervention duration (six months [38]; 12 weeks [39]), dosage of probiotic mixture does not influence the cholesterol-lowering ability of the probiotic mixture.

The intervention of fermented milk with L. acidophilus LA-5 and B. animalis subsp. lactis BB-12 investigated in two studies [32,34] with the same intervention duration (six weeks) showed a significant level of hypocholesterolemic effect in the individuals (almost similar age groups) with T2D; whereas intervention of the same probiotic mixture along with chicory root extract [31] showed significant hypocholesterolemic effect in the healthy subjects even with low dosage of probiotic mixture [31] (when compared to the dosage of probiotic mixture in other studies $[32,34]$ ), which might be due to the duration of intervention (seven weeks) or effect of chicory root extract or depend on the healthy host. Hence, apart from dosage, the duration of intervention plays an important role in influencing the curative effect of probiotics. Therefore, regular consumption of probiotic preparation is required to retain health benefits in the needed host.

\section{Concluding Remarks}

Several studies reported the effect of probiotics on lipid profiles such as TC, TG, LDL-C, and HDL-C levels in different diseased conditions and in healthy volunteers as well, but the results are not conclusive or consistent. The results of the studies suggested that the cholesterol-lowering ability of probiotics is strain-specific, and depends on the host. Studies proposed that the hypocholesterolemic effect of probiotics rely on the bile salt hydrolase activity, production of SCFAs, binding of cholesterol to the cell surface of probiotic, co-precipitation of cholesterol and bile, and conversion of cholesterol into coprostanol of probiotic strain [64].

Some of the human clinical studies have limitations such as probiotic formulations, dosage, duration of the treatment and washout period, no proper follow-up study, etc. Most of the study results conveyed that none of the probiotic supplements have the ability to improve all the desirable parameters, except in some cases. Several probiotics exhibited hypocholesterolemic effect by lowering the TC, LDL-C, and TG levels, and by improving the HDL-C levels in individuals with hypercholesterolemia. The literature survey made in this study suggested that the cholesterol-lowering ability of a probiotic formulation greatly influenced by the factors such as strains of the same bacterial species showed different results, the combination of strains, dose, and duration. Intake of probiotics in capsule form is considered to be more effective in exhibiting beneficial effects. Diet does not significantly influence the cholesterol-lowering ability of the probiotics. Several meta-analyses revealed that the supplementation of probiotic formulations improved the lipid profile. Based on the meta-analysis 
studies, specific probiotic strains such as B. lactis and L. acidophilus, L. plantarum significantly reduced the TC in adult patients [47], and Lactobacillus and Bifidobacterium reduced LDL-C levels in metabolic syndrome patients [48]. Apart from dosage, the intervention duration plays a role in impacting the curative effects of probiotics; thus, regular consumption of probiotic is required to retain health benefits. Further studies are necessary to formulate the probiotic-based therapeutic supplements to control dyslipidemia and to prevent the incidence of CVD.

Author Contributions: Conceptualization, B.S.S.; methodology, B.S.S., and P.K.; writing-original draft preparation, B.S.S.; writing-review and editing, B.S.S., P.K., and C.C.; supervision, B.S.S., and C.C.; project administration, B.S.S., P.K., and C.C.; funding acquisition, C.C.

Funding: This research received no external funding.

Acknowledgments: The authors would like to acknowledge the financial support from Center of Excellence in Medical Biotechnology (CEMB), The S\&T Postgraduate Education and Research Development Office (PERDO), The Commission on Higher Education (CHE), Thailand. Authors gratefully acknowledge Chiang Mai University grant (CMU-grant) for the support.

Conflicts of Interest: The authors declare no conflict of interest.

\section{References}

1. Benjamin, E.J.; Virani, S.S.; Callaway, C.W.; Chang, A.R.; Cheng, S.; Chiuve, S.E.; Cushman, M.; Delling, F.N.; Deo, R.; de Ferranti, S.D.; et al. Heart disease and stroke statistics-2018 update: A report from the American heart association. Circulation 2018, 137, e67-e492. [CrossRef] [PubMed]

2. Heidenreich, P.A.; Trogdon, J.G.; Khavjou, O.A.; Butler, J.; Dracup, K.; Ezekowitz, M.D.; Finkelstein, E.A.; Hong, Y.; Johnston, S.C.; Khera, A.; et al. Forecasting the future of cardiovascular disease in the United States: A policy statement from the American heart association. Circulation 2011, 123, 933-944. [CrossRef] [PubMed]

3. Sun, J.; Buys, N. Effects of probiotics consumption on lowering lipids and CVD risk factors: A systematic review and meta-analysis of randomized controlled trials. Ann. Med. 2015, 47, 430-440. [CrossRef] [PubMed]

4. Scavuzzi, B.M.; Miglioranza, L.H.D.S.; Henrique, F.C.; Paroschi, T.P.; Lozovoy, M.A.B.; Simão, A.N.C.; Dichi, I. The role of probiotics on each component of the metabolic syndrome and other cardiovascular risks. Expert Opin. Ther. Targets 2015, 19, 1127-1138. [CrossRef] [PubMed]

5. Tang, W.H.; Hazen, S.L. The gut microbiome and its role in cardiovascular diseases. Circulation. 2017, 135, 1008-1010. [CrossRef] [PubMed]

6. Yoshida, N.; Yamashita, T.; Hirata, K.I. Gut microbiome and cardiovascular diseases. Diseases 2018, 6, 56. [CrossRef] [PubMed]

7. Hill, C.; Guarner, F.; Reid, G.; Gibson, G.R.; Merenstein, D.J.; Pot, B.; Morelli, L.; Canani, R.B.; Flint, H.J.; Salminen, S.; et al. Expert consensus document: The International Scientific Association for Probiotics and Prebiotics consensus statement on the scope and appropriate use of the term probiotic. Nat. Rev. Gastroenterol. Hepatol. 2014, 11, 506-514. [CrossRef]

8. Food and Agriculture Organization of the United Nations; World Health Organization. Probiotics in food: Health and nutritional properties and guidelines for evaluation. FAO Food Nutr. Pap. 2006, 85, 1-50.

9. Degnan, F.H. The US food and drug administration and probiotics: Regulatory categorization. Clin. Infect. Dis. 2008, 46, S133-S136. [CrossRef]

10. Venugopalan, V.; Shriner, K.A.; Wong-Beringer, A. Regulatory oversight and safety of probiotic use. Emerg. Infect. Dis. 2010, 16, 1661-1665. [CrossRef]

11. Sivamaruthi, B.S. A comprehensive review on clinical outcome of probiotic and synbiotic therapy for inflammatory bowel diseases. Asian Pac. J. Trop. Biomed. 2018, 8, 179-186. [CrossRef]

12. Sivamaruthi, B.S.; Kesika, P.; Prasanth, M.I.; Chaiyasut, C. A mini review on antidiabetic properties of fermented foods. Nutrients 2018, 10, 1973. [CrossRef] [PubMed]

13. Sivamaruthi, B.S.; Kesika, P.; Suganthy, N.; Chaiyasut, C. A review on role of microbiome in obesity and antiobesity properties of probiotic supplements. BioMed Res. Int. 2019, 2019, 3291367. [CrossRef] [PubMed]

14. Blaabjerg, S.; Artzi, D.M.; Aabenhus, R. Probiotics for the prevention of antibiotic-associated diarrhea in outpatients-A systematic review and meta-analysis. Antibiotics 2017, 6, 21. [CrossRef] [PubMed] 
15. Sivamaruthi, B.S.; Kesika, P.; Chaiyasut, C. Influence of probiotic supplementation on climacteric symptoms in menopausal women-A mini review. Int. J. Appl. Pharm. 2018, 10, 43-46. [CrossRef]

16. Sivamaruthi, B.S.; Kesika, P.; Chaiyasut, C. Probiotic based therapy for atopic dermatitis: Outcomes of clinical studies. Asian Pac. J. Trop. Biomed. 2018, 8, 328-332. [CrossRef]

17. Sivamaruthi, B.S.; Prasanth, M.I.; Kesika, P.; Chaiyasut, C. Probiotics in human mental health and diseases-A mini review. Trop. J. Pharm. Res. 2019, 18, 889-895.

18. Sivamaruthi, B.S.; Kesika, P.; Chaiyasut, C. A review on anti-aging properties of probiotics. Int. J. Appl. Pharm. 2018, 10, 23-27. [CrossRef]

19. Mikelsaar, M.; Sepp, E.; Štšepetova, J.; Songisepp, E.; Mändar, R. Biodiversity of intestinal lactic acid bacteria in the healthy population. In Advances in Microbiology, Infectious Diseases and Public Health; Springer: Cham, Switzerland, 2016; Volume 932, pp. 1-64.

20. Upadrasta, A.; Madempudi, R.S. Probiotics and blood pressure: Current insights. Integr. Blood Press. Control 2016, 9, 33-42.

21. Ooi, L.G.; Liong, M.T. Cholesterol-lowering effects of probiotics and prebiotics: A review of in vivo and in vitro findings. Int. J. Mol. Sci. 2010, 11, 2499-2522. [CrossRef]

22. Le, B.; Yang, S.H. Identification of a novel potential probiotic Lactobacillus plantarum FB003 isolated from salted-fermented shrimp and its effect on cholesterol absorption by regulation of NPC1L1 and PPAR $\alpha$. Probiotics Antimicrob. Proteins 2018, 11, 785-793. [CrossRef] [PubMed]

23. Nami, Y.; Bakhshayesh, R.V.; Manafi, M.; Hejazi, M.A. Hypocholesterolaemic activity of a novel autochthonous potential probiotic Lactobacillus plantarum YS5 isolated from yogurt. LWT 2019, 111, 876-882. [CrossRef]

24. Cavallini, D.C.; Manzoni, M.S.; Bedani, R.; Roselino, M.N.; Celiberto, L.S.; Vendramini, R.C.; de Valdez, G.; Abdalla, D.S.; Pinto, R.A.; Rosetto, D.; et al. Probiotic soy product supplemented with isoflavones improves the lipid profile of moderately hypercholesterolemic men: A randomized controlled trial. Nutrients 2016, 8 , 52. [CrossRef] [PubMed]

25. Fuentes, M.C.; Lajo, T.; Carrion, J.M.; Cune, J. A randomized clinical trial evaluating a proprietary mixture of Lactobacillus plantarum strains for lowering cholesterol. Med. J. Nutr. Metab. 2016, 9, 125-135. [CrossRef]

26. Guardamagna, O.; Amaretti, A.; Puddu, P.E.; Raimondi, S.; Abello, F.; Cagliero, P.; Rossi, M. Bifidobacteria supplementation: Effects on plasma lipid profiles in dyslipidemic children. Nutrition 2014, 30, 831-836. [CrossRef]

27. Hlivak, P.; Odraska, J.; Ferencik, M.; Ebringer, L.; Jahnova, E.; Mikes, Z. One-year application of probiotic strain Enterococcus faecium M-74 decreases serum cholesterol levels. Bratisl Lek. Listy 2005, 106, 67-72.

28. Rerksuppaphol, S.; Rerksuppaphol, L. A randomized double-blind controlled trial of Lactobacillus acidophilus plus Bifidobacterium bifidum versus placebo in patients with hypercholesterolemia. J. Clin. Diagn. Res. 2015, 9, KC01-KC04. [CrossRef]

29. Ryan, J.J.; Hanes, D.A.; Schafer, M.B.; Mikolai, J.; Zwickey, H. Effect of the probiotic Saccharomyces boulardii on cholesterol and lipoprotein particles in hypercholesterolemic adults: A single-arm, open-label pilot study. J. Altern. Complement. Med. 2015, 21, 288-293. [CrossRef]

30. Kekkonen, R.A.; Sysi-Aho, M.; Seppanen-Laakso, T.; Julkunen, I.; Vapaatalo, H.; Oresic, M.; Korpela, R. Effect of probiotic Lactobacillus rhamnosus GG intervention on global serum lipidomic profiles in healthy adults. World J. Gastroenterol. 2008, 14, 3188-3194. [CrossRef]

31. Moradi, S.M.; Javidan, A.; Isfahani, H.N. Effects of probiotic ultra-filtered feta cheese and raw chicory root extract on lipid profile in healthy adult volunteers: A triple-blinded randomized controlled trial. Mediterr. J. Nutr. Metab. 2013, 6, 199-206. [CrossRef]

32. Ejtahed, H.S.; Mohtadi-Nia, J.; Homayouni-Rad, A.; Niafar, M.; Asghari-Jafarabadi, M.; Mofid, V.; Akbarian-Moghari, A. Effect of probiotic yogurt containing Lactobacillus acidophilus and Bifidobacterium lactis on lipid profile in individuals with type 2 diabetes mellitus. J. Dairy Sci. 2011, 94, 3288-3294. [CrossRef] [PubMed]

33. Karamali, M.; Dadkhah, F.; Sadrkhanlou, M.; Jamilian, M.; Ahmadi, S.; Tajabadi-Ebrahimi, M.; Jafari, P.; Asemi, Z. Effects of probiotic supplementation on glycaemic control and lipid profiles in gestational diabetes: A randomized, double-blind, placebo-controlled trial. Diabetes Metab. 2016, 42, 234-241. [CrossRef] [PubMed]

34. Tonucci, L.B.; dos Santos, K.M.O.; de Oliveira, L.L.; Ribeiro, S.M.R.; Martino, H.S.D. Clinical application of probiotics in type 2 diabetes mellitus: A randomized, double-blind, placebo-controlled study. Clin. Nutr. 2017, 36, 85-92. [CrossRef] [PubMed] 
35. Abbasi, B.; Mirlohi, M.; Daniali, M.; Ghiasvand, R. Effects of probiotic soymilk on lipid panel in type 2 diabetic patients with nephropathy: A double-blind randomized clinical trial. Prog. Nutr. 2018, 20, 70-78.

36. Kassaian, N.; Feizi, A.; Aminorroaya, A.; Amini, M. Probiotic and synbiotic supplementation could improve metabolic syndrome in prediabetic adults: A randomized controlled trial. Diabetes Metab. Syndr. 2018. [CrossRef]

37. Mafi, A.; Namazi, G.; Soleimani, A.; Bahmani, F.; Aghadavod, E.; Asemi, Z. Metabolic and genetic response to probiotics supplementation in patients with diabetic nephropathy: A randomized, double-blind, placebo-controlled trial. Food Funct. 2018, 9, 4763-4770. [CrossRef]

38. Sabico, S.; Al-Mashharawi, A.; Al-Daghri, N.M.; Wani, K.; Amer, O.E.; Hussain, D.S.; Ahmed Ansari, M.G.; Masoud, M.S.; Alokail, M.S.; McTernan, P.G. Effects of a 6-month multi-strain probiotics supplementation in endotoxemic, inflammatory and cardiometabolic status of T2DM patients: A randomized, double-blind, placebo-controlled trial. Clin. Nutr. 2019, 38, 1561-1569. [CrossRef]

39. Szulińska, M.; Łoniewski, I.; van Hemert, S.; Sobieska, M.; Bogdański, P. Dose-dependent effects of multispecies probiotic supplementation on the lipopolysaccharide (LPS) level and cardiometabolic profile in obese postmenopausal women: A 12-week randomized clinical trial. Nutrients 2018, 10, 773. [CrossRef]

40. Minami, J.; Iwabuchi, N.; Tanaka, M.; Yamauchi, K.; Xiao, J.Z.; Abe, F.; Sakane, N. Effects of Bifidobacterium breve B-3 on body fat reductions in pre-obese adults: A randomized, double-blind, placebo-controlled trial. Biosci. Microbiota Food Health 2018, 37, 67-75. [CrossRef]

41. Kim, J.; Yun, J.M.; Kim, M.K.; Kwon, O.; Cho, B. Lactobacillus gasseri BNR17 supplementation reduces the visceral fat accumulation and waist circumference in obese adults: A randomized, double-blind, placebo-controlled trial. J. Med. Food 2018, 21, 454-461. [CrossRef]

42. Guo, Z.; Liu, X.M.; Zhang, Q.X.; Shen, Z.; Tian, F.W.; Zhang, H.; Sun, Z.H.; Zhang, H.P.; Chen, W. Influence of consumption of probiotics on the plasma lipid profile: A meta-analysis of randomised controlled trials. Nutr. Metab. Cardiovasc. Dis. 2011, 21, 844-850. [CrossRef] [PubMed]

43. Cho, Y.A.; Kim, J. Effect of probiotics on blood lipid concentrations: A meta-analysis of randomized controlled trials. Medicine 2015, 94, e1714. [CrossRef] [PubMed]

44. Shimizu, M.; Hashiguchi, M.; Shiga, T.; Tamura, H.-O.; Mochizuki, M. Meta-analysis: Effects of probiotic supplementation on lipid profiles in normal to mildly hypercholesterolemic individuals. PLoS ONE 2015, 10, e0139795. [CrossRef] [PubMed]

45. Sharma, S.; Kurpad, A.V.; Puri, S. Potential of probiotics in hypercholesterolemia: A meta-analysis. Indian J. Public Health 2016, 60, 280-286. [PubMed]

46. Wu, Y.; Zhang, Q.; Ren, Y.; Ruan, Z. Effect of probiotic Lactobacillus on lipid profile: A systematic review and meta-analysis of randomized, controlled trials. PLoS ONE 2017, 12, e0178868. [CrossRef]

47. Wang, L.; Guo, M.-J.; Gao, Q.; Yang, J.-F.; Yang, L.; Pang, X.-L.; Jiang, X.-J. The effects of probiotics on total cholesterol: A meta-analysis of randomized controlled trials. Medicine 2018, 97, e9679. [CrossRef]

48. Dong, Y.; Xu, M.; Chen, L.; Bhochhibhoya, A. Probiotic foods and supplements interventions for metabolic syndromes: A systematic review and meta-analysis of recent clinical trials. Ann. Nutr. Metab. 2019, 74, 224-241. [CrossRef]

49. Gao, X.; Zhu, Y.; Wen, Y.; Liu, G.; Wan, C. Efficacy of probiotics in non-alcoholic fatty liver disease in adult and children: A meta-analysis of randomized controlled trials. Hepatol. Res. 2016, 46, 1226-1233. [CrossRef]

50. Hendijani, F.; Akbari, V. Probiotic supplementation for management of cardiovascular risk factors in adults with type II diabetes: A systematic review and meta-analysis. Clin. Nutr. 2018, 37, 532-541. [CrossRef]

51. He, J.; Zhang, F.; Han, Y. Effect of probiotics on lipid profiles and blood pressure in patients with type 2 diabetes: A meta-analysis of RCTs. Medicine 2017, 96, e9166. [CrossRef]

52. Mahboobi, S.; Rahimi, F.; Jafarnejad, S. Effects of prebiotic and synbiotic supplementation on glycaemia and lipid profile in type 2 diabetes: A meta-analysis of randomized controlled trials. Adv. Pharm. Bull. 2018, 8, 565-574. [CrossRef] [PubMed]

53. Lewis, S.J.; Burmeister, S. A double-blind placebo-controlled study of the effects of Lactobacillus acidophilus on plasma lipids. Eur. J. Clin. Nutr. 2005, 59, 776-780. [CrossRef] [PubMed]

54. Lee, Y.; Ba, Z.; Roberts, R.F.; Rogers, C.J.; Fleming, J.A.; Meng, H.; Furumoto, E.J.; Kris-Etherton, P.M. Effects of Bifidobacterium animalis subsp. lactis BB- $12^{\circledR}$ on the lipid/lipoprotein profile and short chain fatty acids in healthy young adults: A randomized controlled trial. Nutr. J. 2017, 16, 39. [CrossRef] [PubMed] 
55. Ivey, K.L.; Hodgson, J.M.; Kerr, D.A.; Thompson, P.L.; Stojceski, B.; Prince, R.L. The effect of yoghurt and its probiotics on blood pressure and serum lipid profile; a randomised controlled trial. Nutr. Metab. Cardiovasc. Dis. 2015, 25, 46-51. [CrossRef] [PubMed]

56. Greany, K.A.; Bonorden, M.J.; Hamilton-Reeves, J.M.; McMullen, M.H.; Wangen, K.E.; Phipps, W.R.; Feirtag, J.; Thomas, W.; Kurzer, M.S. Probiotic capsules do not lower plasma lipids in young women and men. Eur. J. Clin. Nutr. 2008, 62, 232-237. [CrossRef] [PubMed]

57. Culpepper, T.; Rowe, C.C.; Rusch, C.T.; Burns, A.M.; Federico, A.P.; Girard, S.A.; Tompkins, T.A.; Nieves, C., Jr.; Dennis-Wall, J.C.; Christman, M.C.; et al. Three probiotic strains exert different effects on plasma bile acid profiles in healthy obese adults: Randomised, double-blind placebo-controlled crossover study. Benef. Microbes 2019, 10, 497-509. [CrossRef]

58. Asemi, Z.; Zare, Z.; Shakeri, H.; Sabihi, S.S.; Esmaillzadeh, A. Effect of multispecies probiotic supplements on metabolic profiles, hs-CRP, and oxidative stress in patients with type 2 diabetes. Ann. Nutr. Metab. 2013, 63, 1-9. [CrossRef]

59. Mahboobi, S.; Iraj, B.; Maghsoudi, Z.; Feizi, A.; Ghiasvand, R.; Askari, G.; Maayeshi, N. The effects of probiotic supplementation on markers of blood lipids, and blood pressure in patients with prediabetes: A randomized clinical trial. Int. J. Prev. Med. 2014, 5, 1239-1246.

60. Razmpoosh, E.; Javadi, A.; Ejtahed, H.S.; Mirmiran, P.; Javadi, M.; Yousefinejad, A. The effect of probiotic supplementation on glycemic control and lipid profile in patients with type 2 diabetes: A randomized placebo controlled trial. Diabetes Metab. Syndr. Clin. Res. Rev. 2019, 13, 175-182. [CrossRef]

61. Ebrahimi, Z.S.; Nasli-Esfahani, E.; Nadjarzade, A.; Mozaffari-Khosravi, H. Effect of symbiotic supplementation on glycemic control, lipid profiles and microalbuminuria in patients with non-obese type 2 diabetes: A randomized, double-blind, clinical trial. J. Diabetes Metab. Disord. 2017, 16, 23. [CrossRef]

62. Mazloom, Z.; Yousefinejad, A.; Dabbaghmanesh, M.H. Effect of probiotics on lipid profile, glycemic control, insulin action, oxidative stress, and inflammatory markers in patients with type 2 diabetes: A clinical trial. Iran. J. Med. Sci. 2013, 38, 38-43. [PubMed]

63. Sabico, S.; Al-Mashharawi, A.; Al-Daghri, N.M.; Yakout, S.; Alnaami, A.M.; Alokail, M.S.; McTernan, P.G. Effects of a multi-strain probiotic supplement for 12 weeks in circulating endotoxin levels and cardiometabolic profiles of medication naïve T2DM patients: A randomized clinical trial. J. Transl. Med. 2017, 15, 249. [CrossRef] [PubMed]

64. Ishimwe, N.; Daliri, E.B.; Lee, B.H.; Fang, F.; Du, G. The perspective on cholesterol-lowering mechanisms of probiotics. Mol. Nutr. Food Res. 2015, 59, 94-105. [CrossRef] [PubMed] 